\title{
Information Systems Stock Inventory in CV Kencana Motor using Laravel Frame
}

\author{
Mukti Ali \\ Software Engineering Technology, \\ Agricultural Management \\ Samarinda State Agricultural \\ Polytechnic \\ Samarinda, Indonesia \\ Muktiali684@gmail.com
}

\author{
Yulianto (iD)* \\ Software Engineering Technology, \\ Agricultural Management \\ Samarinda State Agricultural \\ Polytechnic \\ Samarinda, Indonesia \\ yulianto.tile@yahoo.com \\ *Corresponding author
}

\author{
Emil Riza Putra (D) \\ Software Engineering Technology, \\ Agricultural Management \\ Samarinda State Agricultural \\ Polytechnic \\ Samarinda, Indonesia \\ emilriza92@gmail.com
}

Received: 2020-10-16; Revised: 2021-10-11; Accepted: 2021-10-25; Published: 2021-12-01

\begin{abstract}
- the system for recording stock inventory at CV Kencana Motor, which is done manually, causes errors in recording stock inventory. These errors make the stock item report inaccurate with the original. This study aims to design an income information system and recording stock goods at CV Kencana Motor. The design of this system is made using Data Flow Diagram (DFD) and Contek Digram and Flowchart. The results of this study indicate, this information system built can overcome errors in the calculation of sales transactions, purchases and can overcome the inventory data collection at CV Kencana Motor. Information system at CV Kencana Motor can help in making reports and searching for data more quickly and accurately when needed.
\end{abstract}

Keywords-Laravel, PHP, Website, Information System, Workshop

\section{INTRODUCTION}

The development of technology is currently so fast, one of which is information technology. With the existence of information technology, we not only can get data and information easily and quickly, but the accuracy of the data must also be considered (Murdock, 2018). Inventory of goods or storage of goods, in the context of production, is indispensable for companies, industries, shops and other business entities that carry out the production process (Edi \& Betshani, 2012). The accuracy of data and information on goods in the production process is very important because it will be used as an accounting information report (Martha, et al, 2013)

Workshop CV Kencana Motor is a workshop that has a vision to be the best car repair shop in Samarinda. All kinds of car damage can be served in this workshop with satisfactory results and the increasing number of workshop customers so that professionalism is needed in terms of customer service.

Cashier services at CV Kencana Motor still uses a manual system, as seen from the spare parts inventory system and transaction notes are still recorded on sheets of paper using handwriting and stored in a ledger. This causes the processing of data into information needed by the cashier to not go well. There is an error in writing the types of customer complaints by customer service in the form of work orders that reach $35 \%$, causing inaccuracy problems.

The aforementioned problems are caused by the cashier system that is not well organized, requiring the workshop to implement a cashier system that is capable of processing data quickly, accurately and automatically (computerized) capable of storing and displaying transaction data related to the cashier system so that information produced faster, more accurate and can be managed properly.

Seeing the above conditions, it is necessary to design a computerized cashier information system. This is to increase the competitive advantage of the workshop in providing the best service for customers not only in terms of service but also in terms of cashier services so that customers are more satisfied with the services provided by the workshop.

\section{LITERATURE REVIEW}

\section{A. Study of literature}

Several studies are used as guidelines and references in making applications, among others. Research conducted by Yulia Arianti and Maulana Ashari (2018) entitled the sales information system at the Al-Idan motorbike variation in Karang Baru village, Mataram sub-district, Al-Idan variation shop, Mataram motorbike implemented a sales system and stock information that could help the documentation process. data and solve data loss problems. With a computerized system, to produce an information system for goods data, transaction data and reports stored in the database (Arianti, Ashari, Studi, \& Informatics, 2018). Research conducted by Nono Sudarsono and Sukardi (2015) entitled Web-Based Inventory Information System at PT Autotech Indonesia. PT Autotech Indonesia is a company engaged in the indomobil group, which produces power steering. At this time the inventory information system at PT Autotech Indonesia is still being done manually, so the performance is not yet effective. This is reflected in the 
frequent delays in preparing inventory reports because it takes a long time because they have to recap the data on goods receipts and data on goods expenditures. Therefore, PT Autotech Indonesia intends to computerize the inventory report section system to maximize its performance. It is hoped that after the inventory information system is computerized, the collection, storage, receipt of goods and data on the release of goods can be carried out accurately and quickly (Sudarsono \& Sukardi, 2015).

Research conducted by Wulandari, MM, and Wiwik Sri Rahayu (2014) entitled Web-Based Sales Information System at the Wiwik Colletion Shop so that it can function to promote goods online and convey information will be easier and faster, expand marketing and promotional coverage of deep to international (Wisma \& No, 2014).

Research conducted by Helmi Kurniawan (2015) entitled Web-Based Car Workshop Information System Design, this study aims to solve the problems that occur in the particular workshop, the problem of car maintenance and repair data reports, which in this design uses the Apache software. web, MYSQL database, and Macromedia Dreamweaver. With this system, the problem of car repair customer complaints can be resolved and can improve service to customers (Kurniawan, 2015).

Research conducted by Salih (2019) entitled information system for the sale of Perfume Embun Wangi Berbabis Web, this study aims to help the process of recording sales and purchase transactions of perfume and assist in making reports. This information system was built using the PHP programming language with laravel 5.4 framework and MySQL database. The following comparisons can be seen in table 1 of research comparisons.

Table 1. Comparison of Related Research

\begin{tabular}{|c|c|c|c|}
\hline$\#$ & Name & Year & Title \\
\hline 1 & $\begin{array}{l}\text { Yulia Arianti and Maulana } \\
\text { Ashari }\end{array}$ & 2018 & $\begin{array}{lr}\text { Sales Information } \\
\text { System at AL-IDAN } \\
\text { Motorcycle } \\
\text { Variation } & \\
\text { Karang } & \text { Stores, } \\
\text { Village, } & \text { Mataram } \\
\text { District. } & \end{array}$ \\
\hline 2 & $\begin{array}{l}\text { Nono Sudarsono and } \\
\text { Sukardi }\end{array}$ & 2015 & $\begin{array}{l}\text { Designing a } \\
\text { Website-Based } \\
\text { Goods Inventory } \\
\text { System at } \\
\text { UD.Minang Dewi. }\end{array}$ \\
\hline 3 & $\begin{array}{l}\text { Wulandari, M.M., dan } \\
\text { Wiwik Sri Rahayu }\end{array}$ & 2014 & $\begin{array}{l}\text { Web-Based Sales } \\
\text { Information System } \\
\text { At Colletion Wiwik } \\
\text { Stores. }\end{array}$ \\
\hline 4 & Helmi Kurniawan & 2015 & $\begin{array}{l}\text { Web-Based Car } \\
\text { Workshop } \\
\text { Information System } \\
\text { Design. }\end{array}$ \\
\hline 5 & Salih & 2019 & $\begin{array}{l}\text { Information System } \\
\text { for Sales of Fragrant } \\
\text { Dew Perfume for } \\
\text { the Web. }\end{array}$ \\
\hline
\end{tabular}

\section{B. Information Systems}

Information systems as a collection of groups of subsystems of any component, both physical and nonphysical, are interconnected with each other and work together in harmony to achieve one goal, namely processing data into meaningful and useful information.

The above definition is open to be developed or compiled in a sentence or other format but the basic essence will be the same. As the definition put forward by Loudon in his book "Management Information System; New approaches to Organizations \& Technology say that Information Systems are components that are interconnected and work together to collect, process, store and distribute this information to support the decision-making process, coordination, and control.

Mc. Keown in his book "Management Information System; Managing with Computers "states that an information system is a combination of computers and users that manages changes to data into information and stores that data and information (Ariawan, 2009).

\section{Databases}

Database is a set of data or information that is ordered based on certain criteria that are interconnected. Database is one of the important components in an information system, because it is the basis for providing information, determining the quality of information (accurate, timely and relevant). Information can be said to be valuable if the benefits are more effective than the cost of obtaining it and the database is able to reduce the waste of outside deposits (Minang, Based, \& Rear, 2018).

\section{Context Diagram}

Context diagram is a diagram that consists of a process and describes the scope of a system. Context diagram is the highest level of DFD which describes all the input to the system or the output of the system. He will give an overview of the whole system. The system is bounded by boundaries (represented by dashed lines). In the context diagram there is only one process. There should be no store in the context diagram. Understanding the symbols of the diagram context can be seen in table 2 .

Table 2. Context Diagram

\begin{tabular}{ccl}
\hline Symbol & Name & \multicolumn{1}{c}{ Information } \\
\hline $\begin{array}{c}\text { Source and } \\
\text { destination of } \\
\text { data }\end{array}$ & $\begin{array}{l}\text { External entity is a unit } \\
\text { outside the system } \\
\text { environment which can } \\
\text { be a person } \\
\text { Data Flow } \\
\text { out of the system } \\
\text { The process that } \\
\text { converts from input to } \\
\text { output }\end{array}$ \\
Transformation \\
Process
\end{tabular}

(Rian, 2014)

\section{E. Laravel Framework 5.4}

Laravel is a PHP framework with open code (open source) with an MVC (Model-View-Controller) design which is used to build website applications. 
Model-View-Controller or MVC is a method for creating an application by separating data (Model) from the view (View) and how to process it (Controller).

a. Model, Model represents a data structure. Usually the model contains functions that help someone in database management such as entering data into the database, updating data and others.

b. View, View is the part that controls the view to the user. You could say it is a web page.

c. Controller, Controller is the part that bridges the model and view.

d. The controller contains commands that function to process data and send it to a web page.

Composer is an application-level dependency manager for the PHP programming language that provides a standard format for managing PHP software dependencies and required libraries (Airputih, 2014).

\section{F. Xampp}

Xampp is free software that supports multiple operating systems. Xampp is a compilation of several programs. Its function is as a stand-alone server (localhost) which consists of the Apache HTTP Server program, MySQL database and a language translator written in the PHP and Perl programming languages. The name Xampp stands for X (any four operating systems), Apache, MySQL, PHP and Perl. This program is available under the GNU General Public License and is free. Xampp is an easy-to-use web server that can serve dynamic web page displays.

Xampp essential parts commonly used:

a. Xampp Control Panel Application functions to manage xampp services. Such as activate the service (start) and stop (stop) the service. The display of the Xampp control panel can be seen in Picture 2.1.

b. htdoc is the folder where the files to be run are placed. In Windows, this folder is located at C: I xampp (Hutabarat \& Setyaningsih, 2017).

\section{G. Workshop}

In certain conditions, motorized vehicles require maintenance or repairs. Maintenance and repair of vehicles must be carried out so that the service life of the vehicle is longer or at least equal to the service life predicted and designed by the manufacturer. Even so, car maintenance and repair is not an easy job. This requires special knowledge.

To acquire this knowledge, of course it takes willpower and time. However, most motor vehicle owners usually feel that they do not have these two things. Based on this, there are opportunities for other parties who have expertise and work equipment in the field of motorized vehicles (automotive) to open a workshop business. Transactions occur between people who need maintenance or repair in the automotive sector and those with expertise and equipment in that field. This is done in an automotive repair shop.

\section{LITERATURE REVIEW}

\section{A. Tools and Materials}

The tools used in the study of the Information System of Stock inventory at CV Kencana Motor Web Based Using the Laravel Framework as follows:

1. Hardware (Hardware)

a. Laptop Acer (Ram 4GB DDR3 L Memory, IntelCore i5, 500GB HDD, 14.0 HD LCD)

b. Internet access

2. Software (Software)
a. Xampp
b. MySQL database
c. Sublime Text
d. Google / Mozilla browser
e. Laravel 5.4
f. MySQL Work Bench
g. Visio2013
h. Balsamiq Mockups 3

\section{B. Research Procedures}

\section{System Design (Design)}

In the system design stage, several models will be made including process modeling, database modeling, and program structure.

a. Process Modeling

Process modeling is intended to describe how the system works and all its activities. With the process model, it is hoped that it can make it easier to describe and understand the process that is passed.

Modeling of the DFD level 0 process can be seen in Picture 1 .

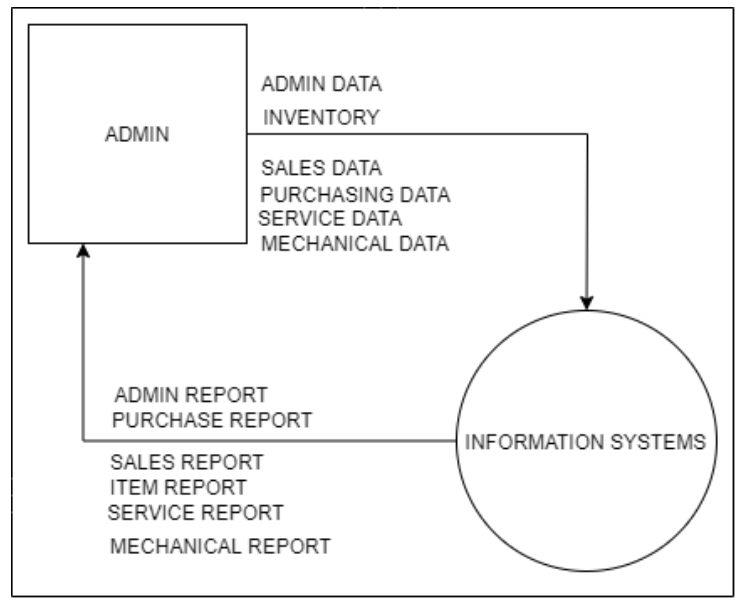

Picture 1. DFD Level 0

Modeling of the level 1 DFD process can be seen in Picture 2. 


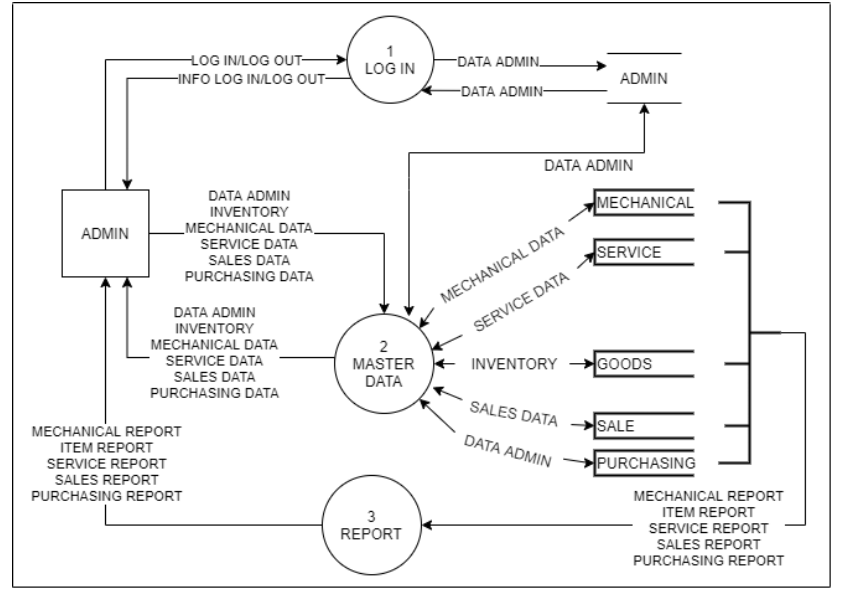

Picture 2. DFD Level 1

\section{RESULTS AND DISCUSSION}

The results of the development of a web-based income and stock information system have eleven menus for admin, namely goods, sales, purchases, services, suppliers, employees, employee salaries, purchase reports, sales reports, service reports and mechanics. This information system was created using the PHP programming language and the laravel 5.4 framework.

1. Login page

The Login page has several input forms to start this application, which can be seen in Picture 3 .

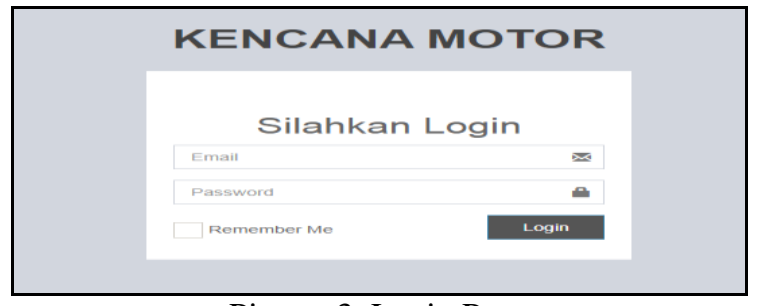

Picture 3. Login Page

2. Home page

The Home page displays several pages that appear after login which can be seen in Picture 4.

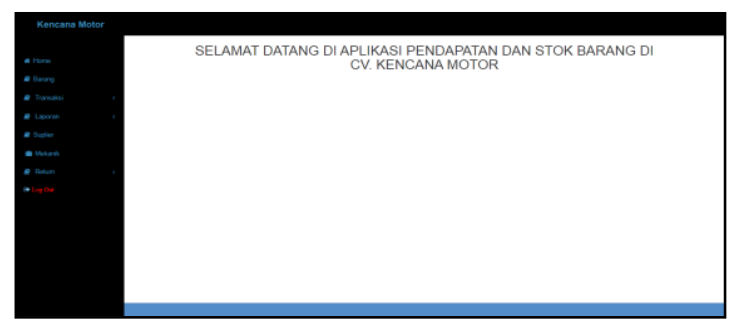

Picture 4. Home Page

3. Item data page

The item data page displays data on the name, selling price, purchase price, stock, unit, damage and wages which can be seen in Picture 5.

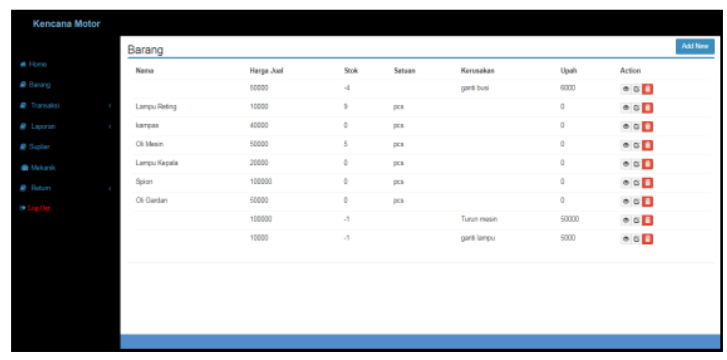

Picture 5. Item Data Page

4. Purchase input page

The purchase data input page displays several forms that the admin can fill in to add purchase data, these forms can be seen in Picture 6 .

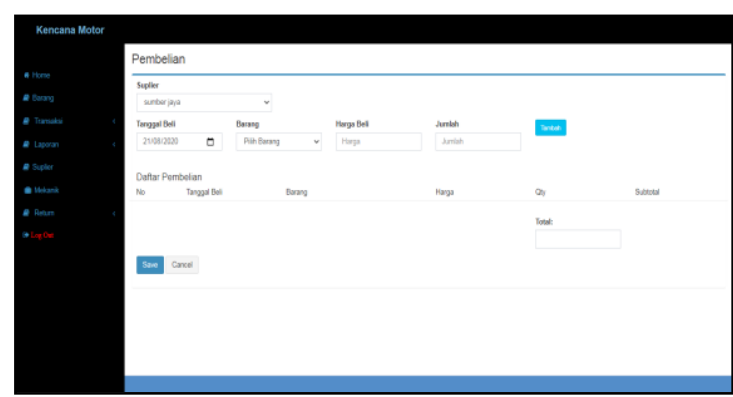

Picture 6. Purchase Input Page

5. Purchase data page

This page displays data that admin has previously input. The purchase page has several actions such as adding new data, deleting data, editing data and seeing the data that can be seen in Picture 7.

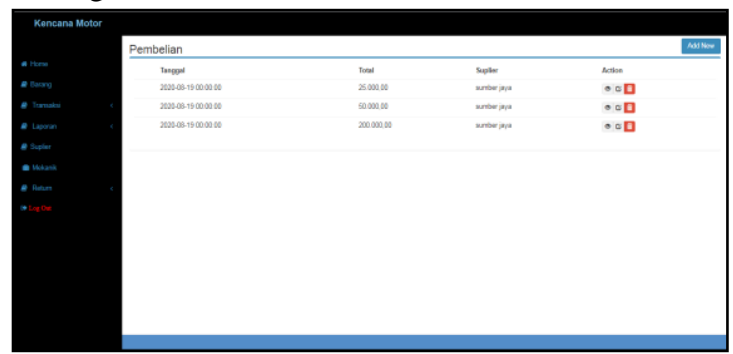

Picture 7. Purchase Data page

6. Sales input page

The sales data input page displays several forms that the admin can fill in to add sales data, these forms can be seen in Picture 8 .

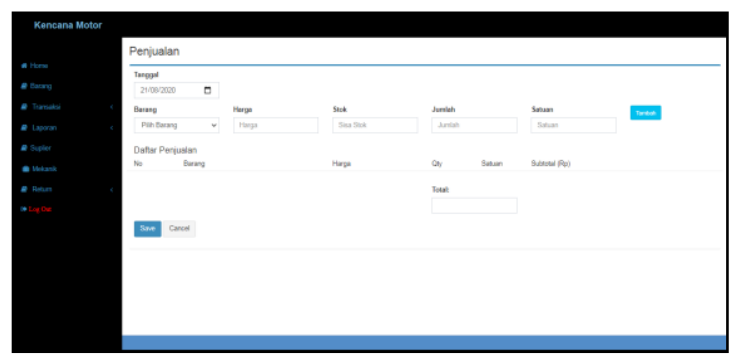

Picture 8. Sales Input Page

7. Sales data page

This page displays data that admin has previously input. The sales page has several actions such as 
adding new data, deleting data, editing data and viewing the data which can be seen in Picture 9.

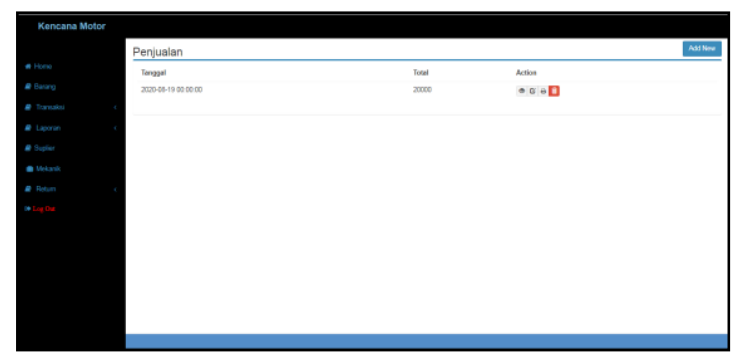

Picture 9. Sales Data Page

8. Service Input page

The service data input page displays several forms that can be filled out by the admin to add service data, the form can be seen in Picture 10.

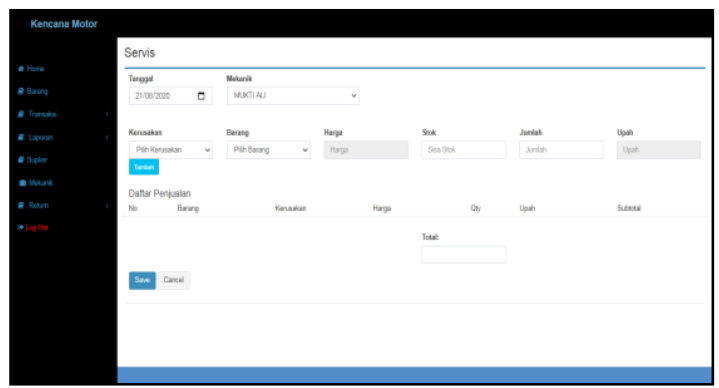

Picture 10. Service Input Page

9. Service Data page

This page displays data that admin has previously input. The service page has several actions such as adding new data, deleting data, editing data and viewing the data which can be seen in Picture 11

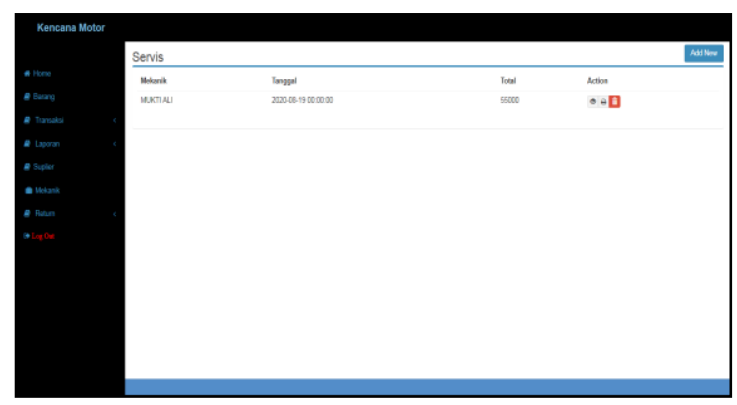

Picture 11. Service Data Page

\section{Sales report page}

The sales report page displays sales data which can be seen in Picture 12.

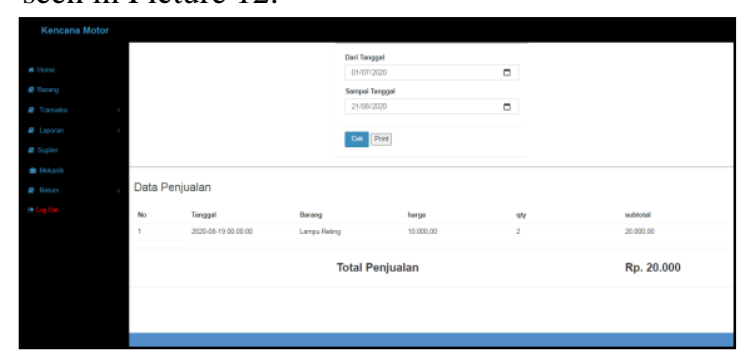

Picture 12. Sales Report Page

\section{Purchase report page}

The purchase report page displays purchase data which can be seen in Picture 13.

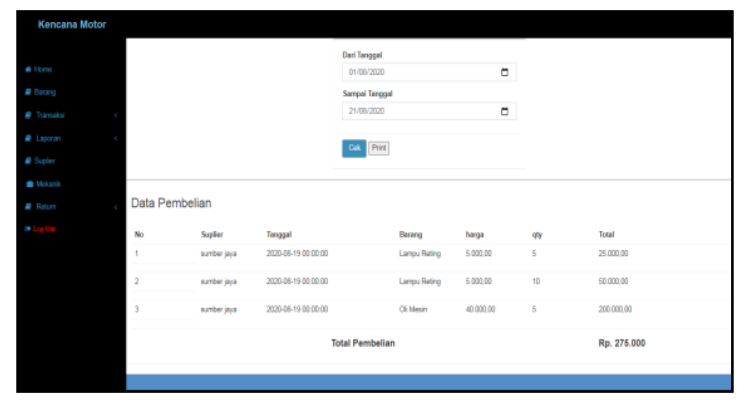

Picture 13. Purchase Report Page

12. Service Report page

Service report page displays service data which can be seen in Picture 14.

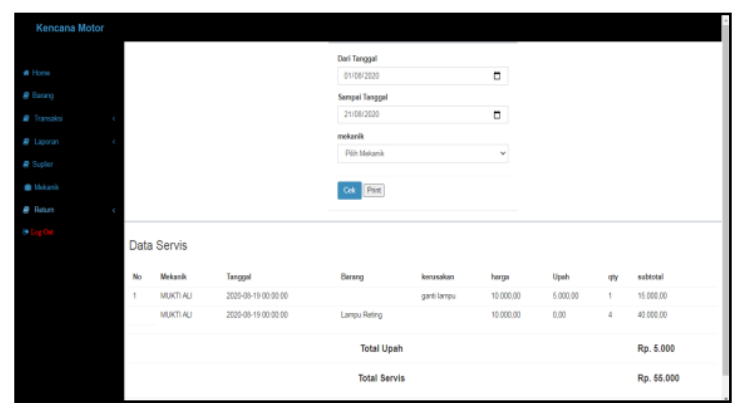

Picture 14. Service Report Page

13. Mechanical Input page

The mechanical data input page displays several forms that the admin can fill in to add mechanical data, these forms can be seen in Picture 15.

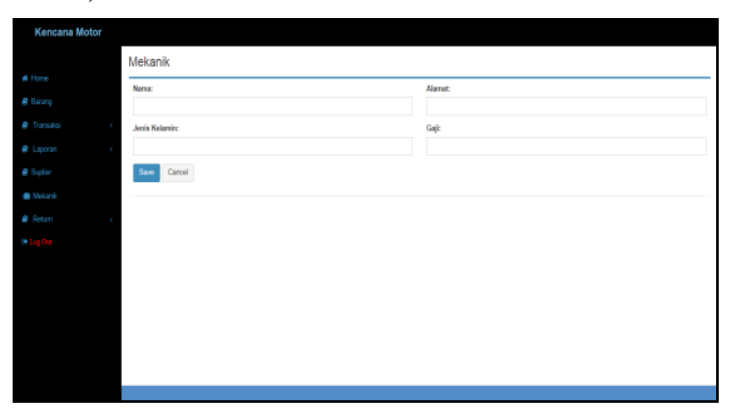

Picture 15. Service Report Page

14. Mechanical Data page

This page displays data that admin has previously input. The Mechanic page has several actions such as adding new data, deleting data, editing data and viewing data which can be seen in Picture 16. 


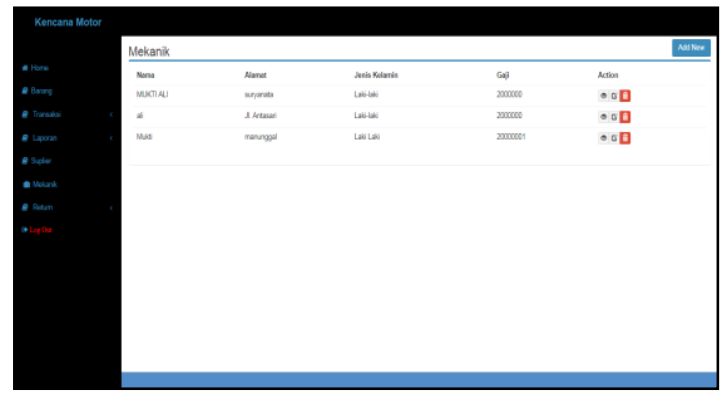

Picture 16. Mechanical Data Page

16. Supplier Input page

The supplier data input page displays several forms that the admin can fill in to add supplier data, the form can be seen in Picture 17.

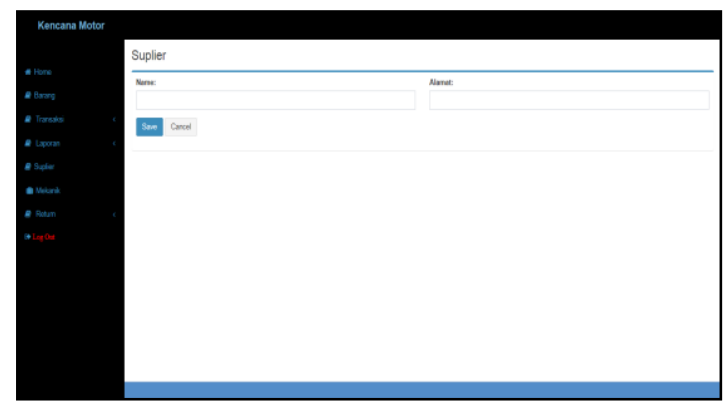

Picture 17. Supplier Input page

\section{Supplier Data page}

This page displays data that admin has previously input. The supplier page has several actions such as adding new data, deleting data, editing data and viewing the data which can be seen in Picture 18 .

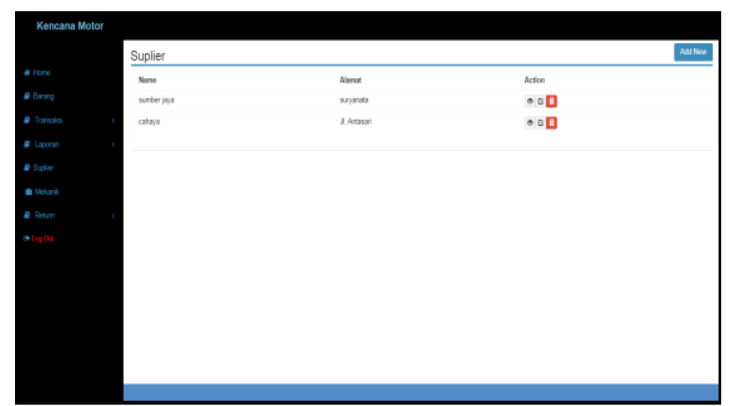

Picture 18. Supplier Data page

\section{CONCLUSIONS}

This information system built can overcome errors in the calculation of sales transactions, purchases and can overcome the data collection of goods at the $\mathrm{CV}$ Workshop. Kencana Motor. With the information system at the CV Workshop. Kencana Motor can help in making reports and searching for data more quickly and accurately when needed.

It is expected that with the information system service process service and sales of spare parts at the CV workshop. Kencana Motor is a computerized service process and sales of spare parts using a database so that the transaction process can be done quickly. In the future, this information system can still be developed, preferably using a barcode system, so there is no need to enter item codes, so that it can facilitate data entry of goods and process of sales transactions. To maintain this data or information system, it is better to back up the data to avoid any damage to the system.

\section{REFERENCES}

Airputih, O. T. (2014). Guide to Laravel PHP Framework.

Arianti, Y., Ashari, M., Studi, P., \& Informatics, T. (2018). Sales Information System at AL-IDAN Motorcycle Variation Stores, Karang Baru Village, Mataram District. 1 (1), 46-51.

Ariawan. (2009). Management Information Systems Textbook. 1, 88.Budiani, N. (2000). Data Flow Diagram: as a system design tool. Computer Application Development Bureau Application System Maintenance Section, (April). Retrieved from http://pranata.kemenkeu.go.id/website/3/DFD as a system design tool.pdf

Edi, D., \& Betshani, S. (2012). Data Analysis Using ERD and the Data Warehouse Conceptual Model. Journal of Informatics, 5 (1), 71-85.

Hanaf, F. (2007). Design of Web-Based Car Workshop Information Systems (Case Study PT Surya Kencana). 1-13.

Hutabarat, M. F., \& Setyaningsih, S. (2017). Web-Based Computerized Data System for Two-Wheeled Vehicle Parts. International Journal of Engineering \& Technology, 1-2, 46-.

Kurniawan, H. (2015). Web-Based Car Workshop Information System Design. Web-Based Car Workshop Information System Design, 9-10.

Martha, A., Priadi, R. A. S., \& Komarudin, M. (2013). Design and Manufacture of Web-Based Camera and Photo Studio Equipment Rental Information Systems. Jitet, 1 (2), 1-10.

Minang, U. D., Based, D., \& Rear, L. (2018). Goods Inventory System Design. 6 (2), 1-7.

Murdock, H. (2018). Auditor Essentials: 100 Concepts, Tips, Tools, and Techniques for Success. CRC Press.

Rian, H. (2014). Designing service information systems at astra honda gandaria jakarta. 2 (1), 1-29.

Sudarsono, N., \& Sukardi. (2015). Web-Based Inventory Information System at PT Autotech Indonesia. Exploration of Informatics, 5 (1), 73-84. Retrieved from https://eksplora.stikombali.ac.id/index.php/eksplora/article/view/79/62.

Wisma, J., \& No, R. (2014). Web-Based Sales Information System at Wiwik Collection Shop Wulandari, M. M., Wiwik Sri Ra. 